\title{
BIODIESEL FROM NYAMPLUNG (CALOPHYLLUM INOPHYLLUM) SEED OIL WITH A TRANSESTERIFICATION PROCESS USING A CONTINOUS FLOW SYSTEM IN THE REACTOR
}

\author{
Yanatra Budi Pramana ${ }^{1}$, Ainul Yakin ${ }^{2}$, Nani Sari Putri ${ }^{3}$, Achmad Miftahul Huda $^{4}$ \\ ${ }_{1,2,3,4}$ Industrial Engineering Department, Faculty of Industrial Technology \\ University of PGRI AdiBuana Surabaya \\ E-mail :_p_yanatra@unipasby.ac.id
}

\begin{abstract}
Biodiesel production from calophyllum inophyllum be obtained via esterification and transesterification, using two continuous reactors with catalyst $\mathrm{NaOH}$ at a concentration $(0.4$ $; 0.6,0.8 ; 1) \mathrm{wt} \%$, calophyllum inophyllum seed oil and reaction temperature $(40,50,60)^{\circ} \mathrm{C}$. This research was to determine the effect of catalyst amount and reaction temperature on transesterification of calophyllum inophyllum seed toward yield Fatty Acid Methyl Ester. The last step is analysis yield of Fatty Acid Methyl Ester with Gas Chromatography (GC). The highest yield is obtained on the amount of $1 \%$ $\mathrm{NaOH}$ catalyst and at a temperature of $60^{\circ} \mathrm{C}$ with yield of $87.036 \%$.
\end{abstract}

Keywords ; FAME, calophyllum inophyllum seed.

\section{INTRODUCTION}

Biodiesel in general is a diesel engine fuel made from renewable or specifically a diesel engine fuel consisting of alkyl esters of fatty acids. Biodiesel can be made from vegetable oil. Biodiesel is expected to replace diesel as a base for diesel engines. The advantages of biodiesel is cetane number higher than the current diesel fuel, exhaust gases from burning biodiesel is more environmentally friendly because it contains almost no SOx gas, better engine acceleration, and lighter pull (Nazef et al,2007). Calophyllum inophyllum seeds can be converted into biofuel with a high yield (estimated at 65\%) and its use is not believed to be competing with an interest in food. Its plants grow and spread evenly calophyllum inophyllum naturally in Indonesia, easy regeneration and fruit throughout the year that showed a high survival ability of the environment (Ajie Rahmansyah, 2009) .

\section{METHODOLOGY}

This research is divided into several steps. The first stage is a preparatory phase which aims to get as much crude oil calophyllum inophyllum seed - which includes many mechanical presses calophyllum inophyllum seeds and gum removal. In the pressing process carried out using screw press by separating the seeds calophyllum inophyllum meat with shell beans, followed by drying the seeds calophyllum inophyllum under the sun for \pm 1 week. And pressing using a screw press calophyllum inophyllum seed. In gum removal process is done by heating the $300 \mathrm{ml}$ seed oil calophyllum inophyllum until a temperature of $50^{\circ} \mathrm{C}$ with a hot plate (heater) was then added $\mathrm{H}_{3} \mathrm{PO}_{4}$ by weight ratio of $0.5 \%$ by weight of the seed oil and heating oil calophyllum inophyllum back while stirring for 30 minutes. After that separates calophyllum inophyllum seed oil (top layer) with no dissolved impurities contained in oil (bottom layer) in the separator funnel. The second step is esterification reaction, performed at a temperature of $60^{\circ} \mathrm{C}$ with methanol (molar ratio of oil: methanol at 1:6) and tested the FFA during the esterification process took place which aims to determine the value decreased FFA levels in raw materials. To the resulting decrease in FFA levels based on an analysis done of at $\mathrm{t}=$ $0 \mathrm{~min}$ value of $\%$ FFA of $0.23 \pm 5.64 \%$ to $1.95 \%$ \pm 0.084 at $t=120$ minutes at the end of the esterification process so that oil can be processed for the next stage. After that the esterified oil is separated using the separator funnel with settling for 12 hours, to form two layers of the upper layer is a residual methanol, water, residual catalyst $\left(\mathrm{H}_{2} \mathrm{SO}_{4}\right)$ and the bottom layer is pretreated oil (methyl esters and triglycerides), then the bottom layer will be used for the transesterification process. The third step is transesterification process in two continuous reactors, followed by entering a solution of 
sodium methoxide $\left(\mathrm{CH}_{3} \mathrm{ONa}\right)$ and the pretreated oil into their respective storage tank and set the flow rate of feed into the reactor. After the reaction mixture continuously at temperatures as variable $\left(40^{\circ} \mathrm{C}, 50^{\circ} \mathrm{C}, 60^{\circ} \mathrm{C}\right)$ for 45 minutes. Next to the separation of biodiesel products (crude FAME) and glycerol by using a separator funnel. The next step is the purification process of washing biodiesel is carried out by measuring the volume of crude biodiesel that is formed from the transesterification process and then wash with warm water $\left( \pm 60^{\circ} \mathrm{C}\right)$ by $30 \%$ by volume of biodiesel. After that do the stirring with a stirrer for 5 minutes, then separates FAME and impurities with a separator funnel. Desired product is located on the top, and bottom layer which is the remaining impurities and their reactants are removed. The washing process is done several times until the washing water is not turbid. After that reduce the water content in biodiesel by heating it to temperature around $110^{\circ} \mathrm{C}$ for 10 minutes. The process was stopped after FAME looks more clear color and have not seen more water content in biodiesel.
And for the last step is analysis of ester content and the yield of FAME by using Gas Chromatography (GC).

\section{RESULT AND DISCUSSION}

Biodiesel product were analyzed yield by using the tools of gas chromatography (GC). Type of Gas Chromatograhy (GC) used was Chromatograhy Gas (GC) - 7900 with column diamensions namely TM-5 x $0.53 \mathrm{~mm} \times 1 \mathrm{~m}$. Compounds used in this analysis of compounds myristic, palmitic, linoleic, oleic, and stearic metyl ester. Fig 1. A set of tools transesterification Caption : 1.Transesterification reactor stirred ; 2 . The oil storage tank; 3.The storage of methanol $+\mathrm{NaOH}$; 4.Underpinnings; 5.Heating jacket; 6.Outflow valve reactor;7.Temperature indicator; 8.Stative and clamp holder; 9.Pump; 10.Power button; 11.Temperaturecontrol; 12 . Stirrer motor; 13.Power supplay motor.

Fig 1. A set of tools transesterification Caption :

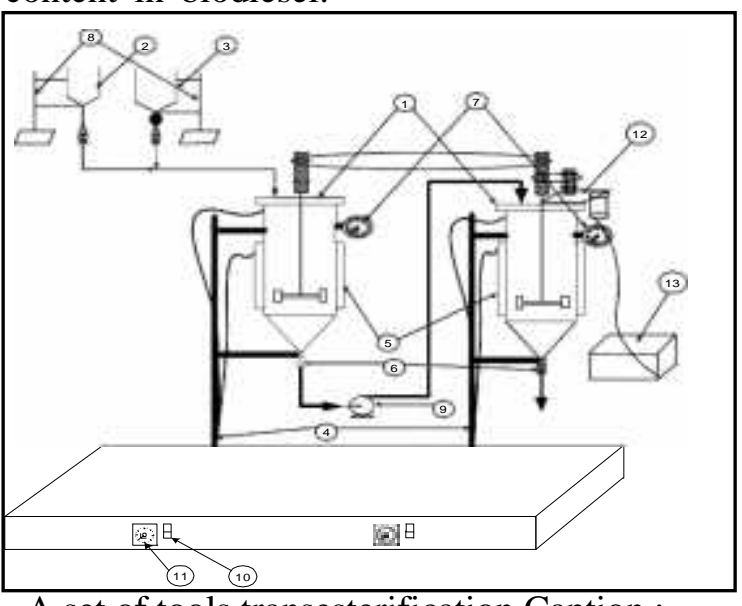

Table 1

Influence of concentration of $(\mathrm{NaOH})$ catalyst to yield FAME at a temperature of $60^{\circ} \mathrm{C}$

\begin{tabular}{lcccc}
\hline No & $\begin{array}{c}\text { Concentration } \\
\text { of NaOH } \\
\text { catalyst } \\
(\% \text { wt oil })\end{array}$ & $\begin{array}{c}\text { Mass } \\
\text { Material } \\
(\mathrm{g})\end{array}$ & $\begin{array}{c}\text { Mass } \\
\text { Product } \\
(\mathrm{g})\end{array}$ & $\begin{array}{c}\text { Yield } \\
(\%)\end{array}$ \\
\hline 1. & 1 & 262,867 & 230,703 & 87,036 \\
2. & 0,8 & 262,867 & 185,726 & 68,806 \\
3. & 0,6 & 262,867 & 166,561 & 58,499 \\
4. & 0,4 & 262,867 & 157,163 & 53,317 \\
\hline
\end{tabular}


Tibuana

Journal of applied Industrial Engineering-University of PGRI Adi Buana

$p$-ISSN 2622-2027

$e$-ISSN 2622-2035

Table 2

Influence of concentration of $(\mathrm{NaOH})$ catalyst to yield $\mathrm{FAME}$ at a temperature of $50^{\circ} \mathrm{C}$

\begin{tabular}{lcccc}
\hline No & $\begin{array}{c}\text { Concentration } \\
\text { of NaOH } \\
\text { catalyst } \\
(\% \text { wt oil })\end{array}$ & $\begin{array}{c}\text { Mass } \\
\text { Material } \\
(\mathrm{g})\end{array}$ & $\begin{array}{c}\text { Mass } \\
\text { Product } \\
(\mathrm{g})\end{array}$ & $\begin{array}{c}\text { Yield } \\
(\%)\end{array}$ \\
\hline 1. & 1 & 262,867 & 222,984 & 83,108 \\
2. & 0,8 & 262,867 & 183,354 & 66,416 \\
3. & 0,6 & 262,867 & 161,534 & 56,290 \\
4. & 0,4 & 262,867 & 154,305 & 52,187 \\
\hline
\end{tabular}

Table 3

Influence of concentration of $(\mathrm{NaOH})$ catalyst to yield $\mathrm{FAME}$ at a temperature of $40^{\circ} \mathrm{C}$

\begin{tabular}{lcccc}
\hline No & $\begin{array}{c}\text { Concentration } \\
\text { of NaOH } \\
\text { catalyst } \\
(\% \text { wt oil })\end{array}$ & $\begin{array}{c}\text { Mass } \\
\text { Material } \\
(\mathrm{g})\end{array}$ & $\begin{array}{c}\text { Mass } \\
\text { Product } \\
(\mathrm{g})\end{array}$ & $\begin{array}{c}\text { Yield } \\
(\%)\end{array}$ \\
\hline 1. & 1 & 262,867 & 197,053 & 69,863 \\
2. & 0,8 & 262,867 & 178,115 & 60,899 \\
3. & 0,6 & 262,867 & 160,591 & 52,369 \\
4. & 0,4 & 262,867 & 147,652 & 43,022 \\
\hline
\end{tabular}

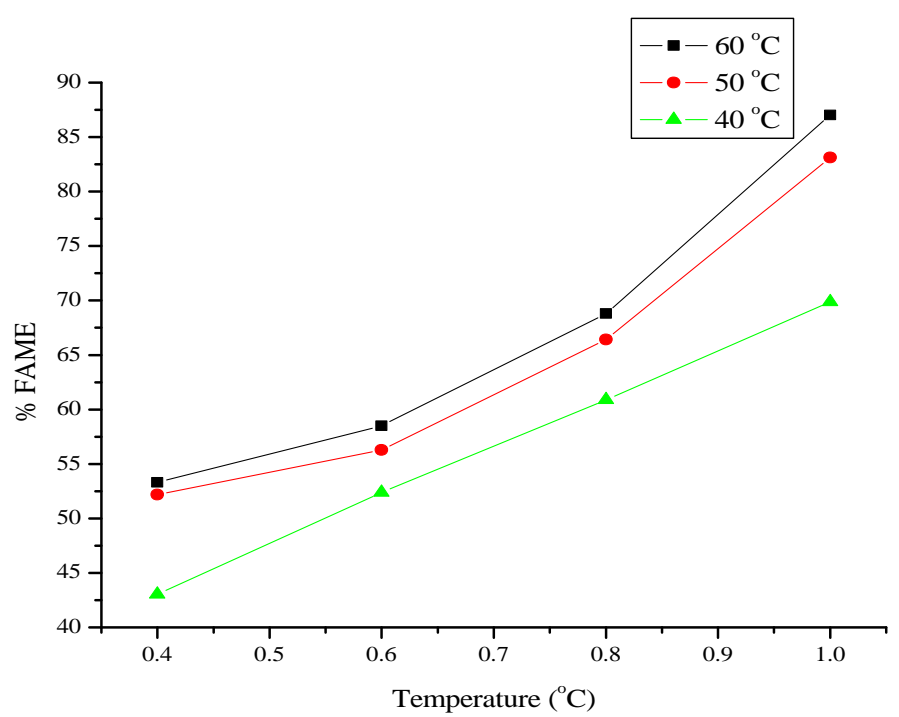

Figure 2 Trial

The addition of base catalyst carried on the process of making crude transesterification of seed oil FAME calophyllum inophyllum. Base catalyst used is sodium hydroxide $(\mathrm{NaOH})$ with variable concentrations of catalyst $(0.4,0.6,0.8$; 1)\% wt calophyllum inophyllum results esterified seed oil. Of these variables, $\mathrm{NaOH}$ will be dissolved into methanol (molar ratio oil: methanol is 1:6) to make sodium methoxide into 
the oil before it is reacted in the process of transesterification. The process of transesterification reactions carried out using two continuous stirred reactors mounted in series. Addition of base catalyst was carried out in the transesterification process of making crude FAME from nyamplung seed oil. The base catalyst used was sodium hydroxide $(\mathrm{NaOH})$ with a catalyst variable concentration of $(0,4 ; 0,6 ; 0,8$; $1) \%$ wt of dried seed oil as a result of esterification. From these variables, $\mathrm{NaOH}$ will be dissolved into methanol (molar ratio of oil: methanol which is 1:6) to make a solution of sodium methoxide before it is reacted into the oil during the transesterification process. The process of transesterification reaction is carried out by using two stirred continuous reactors installed in series, indicating that the greater the addition of the catalyst, the higher the level of ester contained in crude FAME. The reaction

\section{REFERENCES}

1. Crane, Sylvie; Aurore, Guyle'ne; Joseph, Henry; Mouloungui, Ze'phirin; Bourgeois, Paul. 2005. "Composition of Fatty Acids Triacylglycerols and Unsaponifiable Matter in Callophyllum callaba L. Oil from Guadeloupe”. Phytochemistry Vol. $66: 1825-1831$.

2. W Gerpen, J. Van; Shanks, B.; and Pruszko, R.; Clements, D; Knothe, G. 2004. "Biodiesel Production Technology". National Renewable Energy Laboratory (NREL). Colorado.

3. Ketaren, S. 1986. "Pengantar Teknologi Minyak dan Lemak Pangan”. UI Press. Jakarta.

4. Ma; Fangrui; Hanna; M.A. 1999. "Biodiesel production : a review". Bioresource Technology $70: 1-15$. temperature is very influential on the process of making crude FAME, the large or small temperature of the reaction given will affect the yield produced. In this study the transesterification reaction was carried out in two stirred continuous reactors arranged in series which operated at a certain temperature, while the reaction temperature variables used were $40^{\circ} \mathrm{C}$, $50^{\circ} \mathrm{C}$, and $60^{\circ} \mathrm{C}$, from the results obtained, it can be seen that the optimum reaction conditions are the reaction at $60^{\circ} \mathrm{C}$ this is because at a temperature of $60^{\circ} \mathrm{C}$ is the temperature where it has approached the boiling point of methanol which is equal to $64.5{ }^{\circ} \mathrm{C}$ so that methanol can react entirely so that it can give the maximum ester yield so that it will increase the conversion value of the reaction

5. Leevijit, T.; Tongurai, C.; Prateepchaikul, G.; Wisutmethangoon,W. 2008. "Performance test of a 6-stage continuous reactor for palm methyl ester production". Bioresource Technology 99: 214-221.

6. Mittlebach, M.; Remschmidt, Claudia. 2004. "Biodiesel The Comprehensive Handbook". Boersedruck Ges.m.bH. Vienna.

7. Ramadhas, A.S.; Jayaraj, S.; Muraledharan, C. 2004. "Biodiesel Production From high FFA Rubber Seed Oil”. Fuel 84 : 335 340.

8. Venkanna, B.K.; Reddy, C. Venkataramana. 2009. "Biodiesel Production and Optimization from Calophyllum inophyllum Linn Oil (honne oil) - A Three Stages Method". Bioresource Technology $100: 5122-5125$. 